\title{
The Complementary Effects of Islam and CSR: Some Empirical Evidence
}

\author{
Calvin W. H. Cheong (Corresponding author) \\ Faculty of Business, Design and Arts, Swinburne University of Technology Sarawak \\ Jalan Simpang Tiga, 93350 Kuching, Malaysia
}

Tel: 60-82-260-996 E-mail: ccheong@swinburne.edu.my

\begin{abstract}
Nurul Ilma Salleh
Faculty of Business, Design and Arts, Swinburne University of Technology Sarawak Jalan Simpang Tiga, 93350 Kuching, Malaysia

Tel: 60-82-260-985Ｅ-mail: nisalleh@swinburne.edu.my

Fung Chorng Yuan

Faculty of Business, Design and Arts, Swinburne University of Technology Sarawak Jalan Simpang Tiga, 93350 Kuching, Malaysia
\end{abstract}

Tel: 60-82-260-680Ｅ-mail: cfung@swinburne.edu.my

Received: Nov. 29, 2018 Accepted: Jan. 7, $2019 \quad$ Published: June 1, 2019

doi:10.5296/ajfa.v11i1.13976 URL: https://doi.org/10.5296/ajfa.v11i1.13976

\begin{abstract}
This paper empirically investigates what has been claimed in the literature; that there are no significant differences between the Islamic and Western schools of business ethics. A proxy for the Western school is corporate social responsibility (CSR) while in the Islamic school, a reasonable approximation would be Shariah-compliance (SC). But because financial performance is not the main priority in CSR and SC, this study examines the effects CSR and $\mathrm{SC}$ has on firm resilience and firm risk. The regression estimates using an emerging market sample show that both CSR and SC improves firm resilience besides reducing firm risk in the following year. The findings empirically validate the claims made in the literature; that business ethics, Islamic or otherwise, are similar in substance and form. By empirically


examining this claim, this study paves the way for a convergence of values and practices besides fostering greater unity between cultures.

Keywords: Corporate social responsibility, Ethics, Islamic finance, Shariah-compliance, Firm risk, Firm resilience 


\section{Introduction}

The wedge driven between Muslim and non-Muslim communities as a result of recent changes in global geopolitics in the northern hemisphere have led to animosity, social segregation, and even violence between cultures. Central to this demarcation is a lack of understanding among non-Muslims towards Islam, its philosophy and practice. Despite what many opponents of the religion would like to believe, Islam's fundamental underpinnings share remarkable similarities to those of conventional ethical thought and philosophy. A prominent manifestation of Western business ethics is corporate social responsibility (CSR). Ideologically both Islam and CSR agree that accountability and responsibility toward society and the environment at large is, or at least, should be what every company should strive for. While the reasons may vary - for CSR, it is the ethically right thing to do; for Islam, man is the vicegerent and steward of Allah and all Creation - both are in essence, two sides of the same coin (Williams and Zinkin, 2010). Incidentally, there is no Islamic equivalent to CSR within its scriptures as it is implied that a Muslim business owner will embody these principles in managing the enterprise. In a modern context, we can say that the practice of Islamic business principles is personified by the Shariah-compliant (SC) company. Although similar in principle, in practice CSR and SC differ on three fronts: (1) corporate governance, social, and environmental performance; (2) prohibited industries and; (3) financial performance requirements.

As such, this paper aims to empirically investigate the similarities and differences between CSR and SC companies, and the effects these two seemingly substitutable principles may have on the companies that choose to practice them. Instead of the often undertaken comparison of financial performance, this paper examines how CSR or SC affects the resilience and risk levels of companies in the subsequent year. Resilience is the difference in the magnitude of change observed in a particular variable relative to its maximum observed change throughout the sample period, a measure borrowed from the field of ecological economics (Rose, 2004). In this study, the variables are sales revenue, cost of goods sold, operating expenses, and share prices. Firm risk meanwhile is both total risk and idiosyncratic risk (Bouslah et al., 2013). Total risk is the annualized standard deviation from daily stock returns over the preceding year while idiosyncratic risk the standard deviation of the residuals from Carhart's (1997) four-factor model using the previous year's daily excess returns.

Using a sample of 2,125 companies across 14 countries (Note 1) from 2007 to 2014, the ordinary least squares (OLS) estimates show an inverse relationship between the company's socially responsible / Shariah-compliance status and the four indicators of resilience as well as risk. Specifically, by being socially responsible or Shariah-compliant, the sample companies experience greater resilience in terms of their sales, cost, operating expenses and share prices besides lower total and idiosyncratic risk in the following year. The relationship persists even after controlling for a number of firm-level attributes that are known to have an impact on the relationship. We also include the performance of the sample companies' respective asset markets as well as the overall market as a moderating variable in the model. The results show that market performance does have a slight moderating effect but not enough to alter the direction of the relationship. As a robustness test, we examine the effects a 
change in the company's socially responsible / Shariah-compliant status has on its resilience and risk. The results show that losing its status adversely affects its resilience and risk while achieving or maintaining its status improves resilience and risk in the following year. Given these results, it is reasonable to say that both CSR and SC are merely two sides to the same coin as there was no observable differences in their effects on a company's resilience and risk. The contributions of this paper are as follows. First, this paper is to the best of our knowledge, the first paper that empirically substantiates the claims of various studies on the similarities between conventional and Islamic business ethics and philosophy. Second, this paper addresses the need for a cross-cultural perspective on the effects of CSR and Shariah-compliance. Although robust, prior studies on CSR leaves a gap that needs to be filled as they were often based on U.S. or European data. Similarly, studies on Shariah-compliance are largely focused on Muslim majority countries with limited data availability. Finally, by drawing parallels between CSR and Shariah-compliance, this study provides the much needed understanding and compromise between the faith and beliefs of Muslims and non-Muslims alike.

The rest of this paper is as follows. Section 2 provides the review of relevant literature, highlighting the similarities between CSR and Shariah-compliance. Section 3 describes the methodology used in this study. The results and a brief discussion is presented in Section 4. Section 5 concludes.

\section{Literature Review}

\subsection{Shariah-Compliance}

The concept of corporate social responsibility (CSR) and its underlying philosophy has been well documented in the literature and thus needs no reintroduction. Islamic philosophy, especially with regards to business practices, on the other hand, has not enjoyed the same exposure. Rather, since the turn of the century, Islam has incessantly been placed in a negative light by various media outlets (Shadid and van Koningsveld, 2002, 2005; Drees and van Koningsveld, 2008), contributing to the worsening animosity between Muslims and non-Muslims. Things have taken a turn for the worse given recent changes to global geopolitics such as the Brexit referendum and the new U.S. Presidential Administration. But despite these adverse circumstances, the fundamental precepts of Islamic Finance have continued to gain widespread acceptance among financial markets especially in Christian-majority nations, with the introduction of Shariah-compliant financial products and the establishment of Shariah equity indices in the U.S. (e.g. the Dow Jones Islamic Market Index), the U.K. (e.g. the FTSE Shariah Equity Index), or Europe (e.g. the STOXX Europe Islamic Index). The Islamic stock indices offer greater liquidity into the markets whilst providing more opportunities for companies to raise capital. The catch is these companies have to be Shariah-compliant.

Shariah-compliance on the surface is simply a culmination of two criteria: (1) qualitative: is the business involved in prohibited industries, and (2) quantitative: are its finances meeting the permissible thresholds? Prohibited, or haram industries are normally alcohol, pork, conventional financial services such as banking and insurance, entertainment such as hotels, 
casinos, cinemas, and pornography; tobacco; and weapons and defense industries. The quantitative criteria meanwhile generally observe the company's level of interest income, debt, and receivables, following the Islamic prohibition of riba (i.e. interest) and gharar (i.e. risk). If a company meets both the qualitative and quantitative criteria, it is deemed to be Shariah-compliant. Some commentators have argued that while these criteria comply with Islamic principles, it is not a complete reflection of Islamic business ethics. In the following sections, we explore a few key Islamic business principles whilst drawing parallels between Islamic business ethics and CSR.

\subsection{Islamic Business Ethics}

Islamic philosophy is deeply rooted in the principles of stewardship and brotherhood. Mankind was placed on Earth to act as vicegerents of Allah and being bestowed with intelligence, is expected to safeguard the environment by using natural resources that have been gifted in a non-exploitative manner. Also, as all beings are equal in the eyes of God, all human beings are deemed to be in a brotherhood and have a duty to show compassion and help one another in times of need. A responsible or ethical business in Islam is founded upon these principles, complemented by the practices of Prophet Muhammad s.a.w. who Himself, was a tradesman. Even in the Quran, it is explicitly stated that "... God has permitted trade" (Sura al-Baqarah, 275) but not all forms of trade are permitted.

The prohibition on certain industries stems from the principle of protecting health and life. Products and services that may threaten this principle such as alcohol, gambling, and weapons are thus prohibited or haram. Other industries that may potentially degrade ethics and morals through the promotion of obscenities or violence such as entertainment is also prohibited. Gambling, in particular, is prohibited as it represents gains without any serious, productive effort.

A well-known prohibition in Islam is that of interest or riba. Because Islam encourages and rewards hard work, interest is seen as a convenient manner to create profit without having to put in any work. It is feared that this would lead to wealthy capital-owners exploiting the poor and needy, widening the inequality between the groups, and tearing down the moral, social and economic well-being of society (Al-Qaradawi, 1985). Instead, Islam encourages the risk/profit-sharing system, where all parties are jointly responsible for the success or failure of a venture in order to avoid any one party exploiting the other.

Gharar (i.e. speculation or excessive risk-taking) is also a prohibited practice as it exploits the ignorance of the poor and less-informed, causing them to pay a higher price. Because Islam prizes an egalitarian society, information asymmetry is strongly discouraged. As such, business owners are often encouraged to conduct their affairs at "arm's length" where all information about the transaction and the underlying asset is known to all parties to the transaction. Transactions dependent on a leap of faith is thus forbidden.

The responsibilities of the individual, the corporation and the state are clearly defined and deeply rooted in the Quran and Hadith. Prophet Muhammad, in his final sermon (which is commonly taken to exemplify Islamic social responsibility and justice), said: "Verily, you 
will meet your Lord, and He will ask you about your actions. You will neither commit injustice nor will you be wronged. No Muslim is allowed from his brother's property except what he gives away with a good heart; so do not wrong each other. The most honourable of you with Allah is that believer who has morality" (Haykal, 1976: 486-7). His final sermon also serves as a reminder that acting immorally when the rest of society is acting, in the same way, is not excusable; and that every individual is responsible for and bears the consequences of their actions.

\subsection{Islam and CSR}

While a legally binding code of corporate social responsibility does not exist, many attempts have been made in establishing a concise guide as to what constitutes corporate social responsibility and sustainability. Most notable of all is the UN Global Compact, first outlined at the World Economic Forum of 1999. The UN Global Compact aims to foster greater cooperation among companies, UN agencies, labour organizations, and civil society towards establishing and nurturing universal principles of responsible business, and to act as a catalyst for initiatives that support the UN in social and environmental development. Like all CSR guides, the UN Global Compact is not a legal document but instead, relies on public accountability, transparency and a sense of enlightened self-interest in pursuing the principles within. The compact consists of ten principles in the areas of human rights, labour, the environment, and anti-corruption. These principles are summarized in Table 1 below.

Table 1. The ten principles of the UN Global Compact

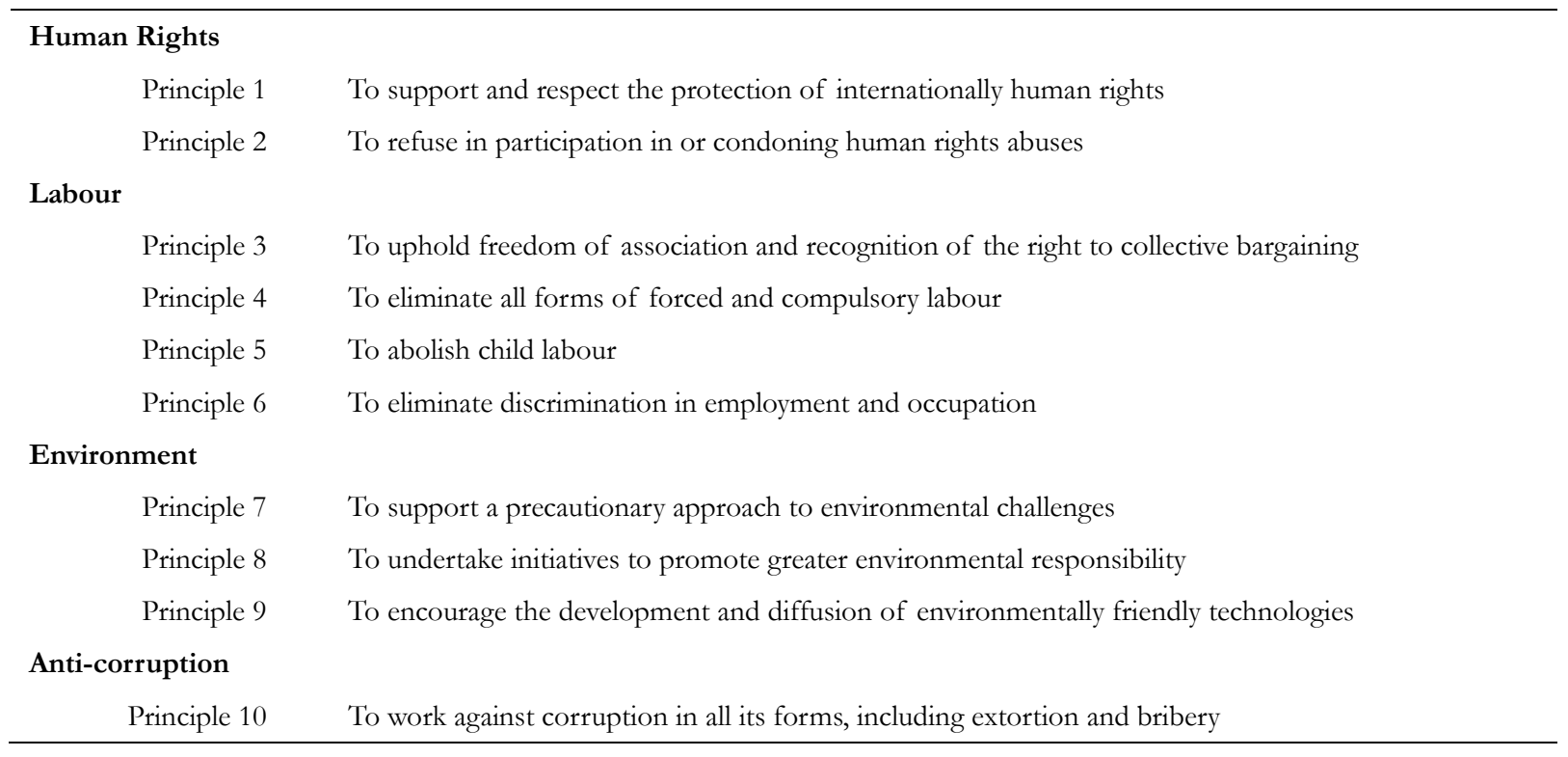

Source: https://www.unglobalcompact.org/what-is-gc/mission/principles, viewed 19 April 2017

These principles are the ten principles of the UN Global Compact are derived from the Universal Declaration of Human Rights, the International Labour Organization's Declaration on Fundamental Principles and Rights at Work, the Rio Declaration on Environment and Development, and the United Nations Convention Against Corruption. These international conventions and declarations have been widely read and applied in various contexts around 
the world. But what is not immediately apparent to many is the fundamental philosophies of these international declarations have existed in Islam for centuries. To illustrate my point, we highlight a few of them in the following paragraphs.

First, as mankind are merely stewards of Allah, Islam recognizes that no one has the absolute right to rule, that governance should be through consultation (Chapra, 2000). That is to say, no individual should hold authority over another individual's personal autonomy and freedom of choice and movement. The Prophet Himself was responsible for the freedom of a large number of slaves over throughout His lifetime. The Prophet also stated that He is opposed to those "... who sold a free person and devoured his price" (Bukhari, 3, p. 258).

Islam also recognizes the right to equal treatment of all mankind as “... we created you from a single (pair) of male and female and made you into nations and tribes that ye may know each other" (Quran, 49, p. 13). Islam also respects the individual freedom of religion and belief - "To you be your way and to me mine" (Quran, 109, p. 6) - and that there will be no compulsion to religion. Instead, Islam respects and honours those that are righteous. The Prophet made this clear in His last sermon: "No Arab has superiority over any non-Arab and no non-Arab has any superiority over an Arab; no dark person has superiority over a white person and no white person has any superiority over a dark person. The criterion of honour in the sight of Allah is righteousness and honest living" (the Prophet's Last Sermon). A lesser known aspect of equal treatment in Islam is that women's rights are equal to men. There are many instances within the Quran where this is evident (For example Quran, 4; 7; 3). Superiority in Islam is only on the basis of virtue and righteousness (Quran, 49, p. 13). It is only in modern times that these teachings and virtues have been misinterpreted due to inherent cultural biases (UNDP, 2002).

With regards to social and economic well-being, Islam recognizes the importance of a basic standard of living through the establishment of zakat or obligatory charity. Zakat contributions are made by Muslims who are better off to provide a minimum social safety net for their less fortunate brothers and sisters in Islam. Beyond zakat, Muslims are strongly encouraged to engage in charitable giving since "... in their wealth, there is a due share for the needy and deprived" (Quran, 51, p. 19). Besides helping the impoverished, Muslims are also required to aid the personal development of his fellow Muslim, to guide them to the right path when they have strayed, and to stand up against any form of oppression (Hadith Muslim, Book 3, No. 6246).

The teachings within the Quran and Hadith are explicit on the need for Muslims to protect and preserve the natural environment. Because mankind is simply the vicegerent of Allah, he serves as a steward of the natural environment and is responsible for its protection (Quran, 6, p. 165). As mankind is ultimately answerable to Allah, he faces punishment if he does not perform his duties to preserve and protect nature that rightfully belongs to Allah (Quran, 4, p. 126). It has been widely cited that the Prophet had established natural reserves to protect wildlife and preserve natural resources. As a result, scholars have through the principle of qiyas, extrapolated this example set by the Prophet to mean environmental protection legislation (Beekun and Badawi, 2005). Despite its stance on environmental preservation, 
Islam also recognizes the human need to use natural resources for daily life and economic work but cautions against wastage and encourages moderation (Quran, 7, p. 31).

Finally, Islam adopts a strict stance against corruption and promotes ethical business conduct (Al-Qaradawi, 1985). Additionally, given the strict prohibition on gharar, Islam strongly encourages transparency in business dealings; that all business transactions are written contracts with all relevant information made clear to all contracting parties at the point of agreement. As such, the principle of caveat emptor prevalent in modern society is forbidden. Trustworthiness and honesty in the transaction especially with regards to the quality and standards of the underlying traded commodities are also explicitly stated in the Quran $(6 ; 17$; $83)$.

The fundamental philosophy of CSR is based on similar, if not the same, principles. Companies are expected to be mindful of the environment they operate in, proactively engage in projects that promote social development and protect the rights of its workers and consumers whilst owing a responsibility to its shareholders to earn a profit. According to CSR principles, these initiatives are the responsibility of the managers, not the owners (i.e. shareholders). Islam, on the other hand, makes no distinction between the owner (or manager) and the firm: the firm is deemed to be a part of the owner (or manager) and is as such, expected to fulfill the same responsibilities borne by the owner.

The principles of environmental stewardship, caring for the community or brotherhood, and avoidance of questionable business practices are but a few of the many similarities shared between the fundamental principles of CSR or corporate sustainability and the Islamic notion of an ethical and responsible business. In practice, however, differences between these concepts are more apparent. Arguably, the practice of CSR or corporate sustainability arises from corporate altruism. But it may also stem from the need to appease the public and to maintain legitimacy. Ethical and responsible business practices, on the other hand, is a religious obligation for all Shariah-compliant businesses. As a result, in the pursuit of CSR, companies have to still place emphasis on financial gains. Similarly, Islam encourages trade (Quran, Sura al-Baqarah, 275) and the pursuit of financial gain, so long as it has been obtained through ethical and responsible practices.

As the preceding discussion suggests, Islam and CSR are profoundly similar in principle. The key difference lies in its practice. CSR manifests itself in the form of companies that actively pursue CSR objectives. Islamic business principles, on the other hand, are not quite that easy to place. The closest approximation is the Shariah-compliant company as it meets most of the Islamic business principles discussed earlier: prohibition on haram industries; prohibition on risk and excessive risk-taking, the provision of zakat; respect and protection of human and labour rights; protection and preservation of the natural environment; and abstinence from corrupt practices. With this in mind, we make comparisons between CSR and Shariah-compliance in the following section.

\subsection{CSR and Shariah-compliance: Contrary or complementary?}

In theory, both of these concepts are noble aspirations that companies should ideally strive for. 
However, the true meaning of CSR and Shariah-compliance seems to have been lost in practice. Many companies, despite grand, benevolent gestures of social and environmental responsibility, have failed to uphold the essence of CSR. A good example of this would be Royal Dutch Shell who in early 2015 caused a massive oil spill in Nigeria (BBC, 2015) that polluted the waterways resulting in irreparable damage to the local environment besides disrupting the livelihood of the natives for many years to come. This is in spite of their thorough CSR strategic plan communicated to the masses in their media relations. The hypocrisy is not limited to CSR companies alone. The principles of Islamic economics and finance, as well as the concept of Shariah-compliance, have also been subjects of substantive criticism. Critics contend that the 'Islamic' terminology used in practice and in literature are merely different in form rather than substance from their conventional counterparts (see Khan, 2010; El Gamal, 2006; Kuran, 2004; Zaman, 2002; Nomani; 2006). Given such harsh criticism, why do companies still insist on being socially responsible or Shariah-compliant? The literature abounds with arguments for the 'business case' of these hotly debated concepts. We briefly summarize these arguments in the following paragraphs.

Davidson and Worrell (1988) and Davidson, Worrell, and Lee (1994) examined a firm's stock return response to corporate illegalities and found that stock markets react negatively when a firm was embroiled in bribery, tax evasion, and violation of government contracts. The authors also found the magnitude of negative reaction to being greater for repeat offenders. Balabanis, Phillips, and Lyall (1998) meanwhile found firm's that performed well in the previous year were more likely to partake in philanthropic activities in the next year. Stanwick and Stanwick (1998) likewise found a strong correlation between profitability and a firm's likelihood of being socially responsible. McWilliams and Siegel (2000) meanwhile argued that R\&D and advertising expenditure contributed towards a firm's level of CSR. Public disclosure of CSR activities has also been found to affect share price returns (Murray, Power, and Gray, 2006) and cost of equity capital (Dhaliwal, Li, Tsang and Yang, 2011). Following stakeholder theory, better CSR performance lowers firm risk through reduced financial and operating risks (McGuire et al., 1988.) as well as social and environmental risks (Feldman et al., 1997; Sharfman and Fernando, 2008). CSR engagements may also reduce information asymmetries as it may be perceived as a signal of greater management quality (McGuire et al., 1988; Waddock and Graves, 1997). Strategic investment in CSR initiatives such as environmental relations and product innovation suggests to stakeholders that their expectations are taken seriously by the firm, thereby contributing to lower firm risks (Surroca et al., 2010.). Similarly, Durand et al. (2013) found societal values to exert significant pressure on "sin" firms resulting in lower fund manager interest, poorer analyst coverage, lower share prices, and a higher likelihood of being shunned by equity markets which contribute to greater risk.

Shariah-compliant companies, on the other hand, have not attracted so much interest due to a lack of data. We briefly review a few here. In a study on the pecuniary costs of an investor's compliance with Shariah, Hakim and Rashidian (2004) observed Treynor ratios, risk-return tradeoffs, and correlations to the Dow Jones Islamic index. Their findings showed that Shariah restrictions did not expose investors to risks greater than what the investors would 
have had if they had invested in a broad market index. In a comparative study between Islamic and conventional mutual funds, Elfakhani, Hassan and Sidani (2005) likewise found that the performance of both funds do not differ enough to warrant investors making a choice between the two based solely on returns. Albaity and Ahmad (2008) arrived at similar conclusions in their comparative study between the Kuala Lumpur Shariah and Composite Index. In fact, their tests results suggest that the movement of the Shariah Index may actually be predicted by the Composite Index. Using firm-level data in the Malaysian plantations industry, Dali, Mudasir and Abdul Hamid (2008) similarly found no statistically significant difference in the performance of Shariah and non-Shariah compliant companies. In what is arguably one of the most mathematically rigorous studies on Shariah-compliance, Derigs and Marzban (2009) constructed an optimized equity portfolio based on Shariah precepts. Their Shariah-compliant optimized portfolio performed significantly better than other normally available Shariah-compliant portfolios besides performing as well as its conventional counterparts within the same asset universe. Alam and Rajjaque (2010) meanwhile, found Shariah-compliant equity returns to be more resilient during periods of market turmoil but underperform their conventional counterparts when the market is bullish. Hoepner, Rammal, and Rezec (2011) similarly found Islamic equity funds based in Muslim-majority countries to outperform international equity indices. Those based in Christian-majority nations or in countries where Islamic finance has yet to gain widespread acceptance underperformed their benchmarks. Perhaps the best empirical evidence that suggests Shariah-compliance and CSR are not that different comes from Abdelsalam et al. (2013) who found no statistically significant difference in the efficiency and performance of Shariah-compliant and socially responsible investment funds.

Given the fundamental similarities between CSR and Shariah-compliance, it is reasonable to assume that the effect/s of CSR performance on various firm performance measures can also be observed in Shariah-compliant firms. In fact, the effects on Shariah-compliant companies may be more profound for a number of reasons. Ideally, the firm is expected to exhibit a conscience towards the natural environment besides imparting a greater sense of benevolence upon the community. These expectations naturally stem from a growing social conscience towards the environment and community, pressuring companies to reflect this conscience or risk losing its corporate legitimacy. In this regard, Shariah-compliant companies are placed under greater scrutiny due to their religious foundations. Not only do they have to meet environmental and social expectations but religious expectations as well. Following this argument, it is possible that Shariah-compliant companies are more sensitive to changes in market expectations and will experience greater variability in firm performance i.e. they are less resilient as compared to good CSR performance companies during periods of economic distress. The hypothesis to be tested is thus:

Hypothesis 1: Shariah-compliant companies are less resilient than good CSR performance companies during periods of economic distress, ceteris paribus.

Islamic businesses ideally should not be involved with gharar or risk. But at the same time, Islam accepts that riskless business ventures do not exist. Rather, Islamic businesses are encouraged to avoid investing in risky projects or taking on excessive risks as far as it is 
reasonable for the wellbeing of the business. Additionally, the Islamic prohibition of "sin" industries such as alcohol, tobacco, gambling, firearms, and other haram industries should technically lower a Shariah-compliant company's level of firm risk (Durand et al., 2013.). The prohibition on industry involvement may, however, be a double-edged sword as it increases the company's concentration risk and reduces its ability to diversify its operations into other more profitable industries.

Attig et al. (2013) argue that firms can reduce their perceived risk of financial distress by signaling their availability and efficient allocation of the firm's internal resources through their CSR initiatives. Firms that actively pursue CSR objectives are more likely to disclose their CSR activities (Dhaliwal et al., 2011.) and are consequently more transparent, thereby reducing informational asymmetries between the firm and investors, thus mitigating firm risk. In contrast, there is a need for Shariah-compliant companies to improve the disclosure of their activities especially those that fall under the direct purview of Shariah-compliance screening criteria. Furthermore, Shariah-compliant equity or debt issues: (1) in principle, have not been treated in the same manner as conventional instruments for accounting purposes and; (2) generally do not hold the same level of transparency as their conventional counterparts due to pricing mechanisms that are based upon an underlying commodity that is not fully disclosed (PricewaterhouseCoopers, 2010). The absence of a reliable and independent assessment of these risks makes it difficult for market participants to evaluate the company's level of risk. Given the additional restrictions imposed upon Shariah-compliant companies and the lack of voluntary disclosure on their operations and investments, Shariah-compliant companies are likely to exhibit greater levels of firm risk as compared to good CSR performance companies. The hypothesis to be tested is thus:

Hypothesis 2: Shariah-compliant companies are riskier than good CSR performance companies, ceteris paribus.

\section{Methodology}

\subsection{Defining a Socially Responsible and Shariah-compliant Company}

Most firm-level studies on CSR utilize data from MSCI ESG STATS (formerly known as KLD Research Analytics Inc.). However, MSCI only provides CSR information for US companies. In this paper, we use CSR information provided by RobecoSAM, a Zurich-based investment company. Every year RobecoSAM surveys thousands of companies around the world in their Corporate Sustainability Assessment (CSA) exercise. The CSA comprises a series of questions that evaluate companies on their performance in three broad categories: Economic, Environmental, and Social. The scores compiled from the CSA forms the opinion of the Dow Jones to include or drop companies from its Sustainability Index. Because the CSA scores are proprietary, RobecoSAM publishes the annual Sustainability Yearbook wherein it lists the companies that are in the top $15 \%$ of their respective industries CSR-wise. For the purpose of this paper, a socially responsible company (SR) is defined as a company that has been listed in the Sustainability Yearbook for the given year. Because the Sustainability Yearbook is normally published during the fourth quarter of each year, some questions may arise as to the exact timing of the information. As the information in the 
Yearbook takes some time to be compiled, it is assumed that the contents of the Yearbook reflect the company's CSR efforts as at January of the year the Yearbook was published.

The different interpretations of Islamic principles derived from the various Islamic sects makes defining Shariah-compliance a trickier affair. Generally, for a company to be deemed Shariah-compliant, it must meet both qualitative and quantitative criteria. For consistency, a Shariah-compliant company is defined as a company that has met the Dow Jones Islamic Market Index (DJIMI) Shariah-compliance criteria, regarded among commentators as the most conservative (Khatkatay and Nisar, 2006; 2007; Derigs and Marzban, 2008) yet inclusive (Derigs and Marzban, 2009). The DJIMI's Shariah Supervisory Board's qualitative criteria establishes the following broad categories of industries considered haram: alcohol, pork, conventional financial services such as banking and insurance, entertainment such as hotels, casinos, cinemas and pornography, tobacco; and weapons and defense industries. The quantitative criteria meanwhile are the company's level of debt, level of interest earnings, and level of receivables. Level of debt is defined as the company's total debt divided by its trailing 24-month average market capitalization; level of interest earnings is the sum of company's cash and interest-bearing securities divided by its trailing 24-month average market capitalization, and level of receivables is the company's total accounts receivables divided by its trailing 24-month average market capitalization. The maximum acceptable threshold for these three measures as prescribed by the DJIMI is 33 percent. If the company does not belong to a haram industry, and meets the 33 percent threshold, it is thus recognized as a Shariah-compliant company (SC).

\subsection{Dependent Variable}

\subsubsection{Firm Resilience}

To borrow a term from the ecological economics literature, resilience is defined as the inherent and adaptive responses to external shocks that firms undertake to avoid potential losses, with emphasis on the ingenuity and resourcefulness applied during and after the event (Rose, 2004). Following this definition, firm resilience can be measured across a number of indicators that are most susceptible to market-wide phenomenon. In this paper, firm resilience, $F R$, is measured using an adaptation of Rose (2004), defined as:

$$
F R=\frac{\% \Delta D Q^{\max }-\% \Delta D Q}{\% \Delta D Q^{\max }}
$$

where $\% \Delta D Q^{\max }$ is the maximum percentage change in the observed indicator and $\% \Delta D Q$ is the percent change in the observed indicator, on a monthly basis. A lower $F R$ value indicates greater resilience. The indicators observed in this study are the company's sales revenue, cost of goods sold, operating expenses, and share price. The intuition behind the choice of indicators is simple. A company's sales revenue and cost of goods sold is to a great extent, dependent on its ability to inspire and attract customers, and to build strong relationships with its suppliers. Prior studies (e.g. Kotha, Rajgopal and Rindova, 2001; Lev, Petrovits, and Radhakrishnan, 2010) have established that CSR has a profound positive impact on a firm's relationships with its customers and suppliers. Operating expenses is included as one of the 
indicators of resilience as a reflection of managerial efficiency since active engagement in CSR activities is a sign of efficient allocation of resources (Attig et al., 2013). Share price is the final resilience indicator as it reflects the market's sentiments towards the company and its activities. Companies in controversial industries exhibit greater share price volatility while socially responsible companies have lowered firm risk (Durand et al., 2013; Jo and Na, 2012).

\subsubsection{Firm Risk}

Following Bouslah et al. (2013), total risk is measured by the annualized standard deviation from daily stock returns over the preceding year. Idiosyncratic risk is measured as the standard deviation of the residuals from Carhart's (1997) four-factor model using the previous year's daily excess returns. Carhart's four-factor model is as follows:

$$
R_{i t}-R_{f t}=\alpha_{i}+\beta_{i m}\left(R_{m t}-R_{f t}\right)+\beta_{i s} S M B_{t}+\beta_{i h} H M L_{t}+\beta_{i u} U M D_{t}+\varepsilon_{i t}
$$

where $R_{i t}$ is the return of firm $i$ for day $t . R_{f t}$ is the risk-free rate (based on 1-month T-bill rate). $\left(R_{m t}-R_{f t}\right)$ is the excess return of the market portfolio (the local stock market index) for day $t$. $S M B_{t}$ is the difference between the returns on portfolios of "small" and "big" capitalization stocks for day t. HML $L_{t}$ is the difference between the returns on portfolios of "high" and "low" book-to-market stocks for day t. $U M D_{t}$ is the difference between the returns on portfolios of high and low prior return stocks. $\varepsilon_{i t}$ is the stochastic error term, assumed to be IID normal with mean zero and constant variance $\sigma_{\varepsilon_{i}}^{2}$. For each firm-year observation, we use daily excess returns over the previous year to estimate idiosyncratic risk using time series regressions. This process is repeated for each year throughout the sample period to obtain a time-varying idiosyncratic risk.

\subsection{Control Variables}

Following theoretical arguments and empirical evidence presented in prior studies (see for example, Fama and French 1992; 1993; Brennan et al., 1998; Gebhardt et al., 2001; Chordia et al., 2001; Botosan and Plumlee, 2005; and Bouslah et al., 2013) the firm-specific control vaiables included in this study are firm size, book-to-market $(B / M)$ ratio, net leverage, expected return, stock liquidity, liquidity risk, return-on-assets, investment-to-asset ratio, expected growth in earnings, default risk and investor base.

Firm size is the logarithm of the market value of common equity at the most recent fiscal year end prior to the measurement date of the risk measures used to account for the highly skewed nature of this variable. Book-to-market $(\mathrm{B} / \mathrm{M})$ ratio is measured as the ratio of the book to market value of common equity as of the most recent fiscal year end. Following Bates et al., (2009) this study also includes net leverage, measured as the ratio of long-term debt minus cash and marketable securities to the market value of common equity using values for the most recent fiscal year end. The study uses annualized return from the previous year's daily stock returns to proxy for expected return. The level of stock liquidity is measured by the average daily share turnover, while liquidity risk is the coefficient of variation of the average daily share turnover. Share turnover is defined as daily shares traded divided by daily shares outstanding. 
This study also uses the standard deviation of the return on assets (ROA) over the previous 5 years to control for cash flow risk. Investment-to-asset ratio is computed as the sum of capital expenditures, research and development expenditures and advertising expenses, divided by total assets. This study uses the mean annualized 5-year earnings growth rate estimated as the implicit growth in forecasted earnings from year 1 to year 2 to proxy for expected growth in earnings. Default risk is measured using Altman's (1993) Z score. A higher value of the Z score indicates a lower likelihood of default. Following Merton's (1987) argument, this study also includes the investor base, measured as the number of common ordinary shareholders divided by common shares outstanding. The descriptive statistics of these variables for both the socially responsible and Shariah-compliant companies are presented in Table 2 below.

Table 2. Descriptive Statistics of Dependent and Control Variables, 2007 - 2014

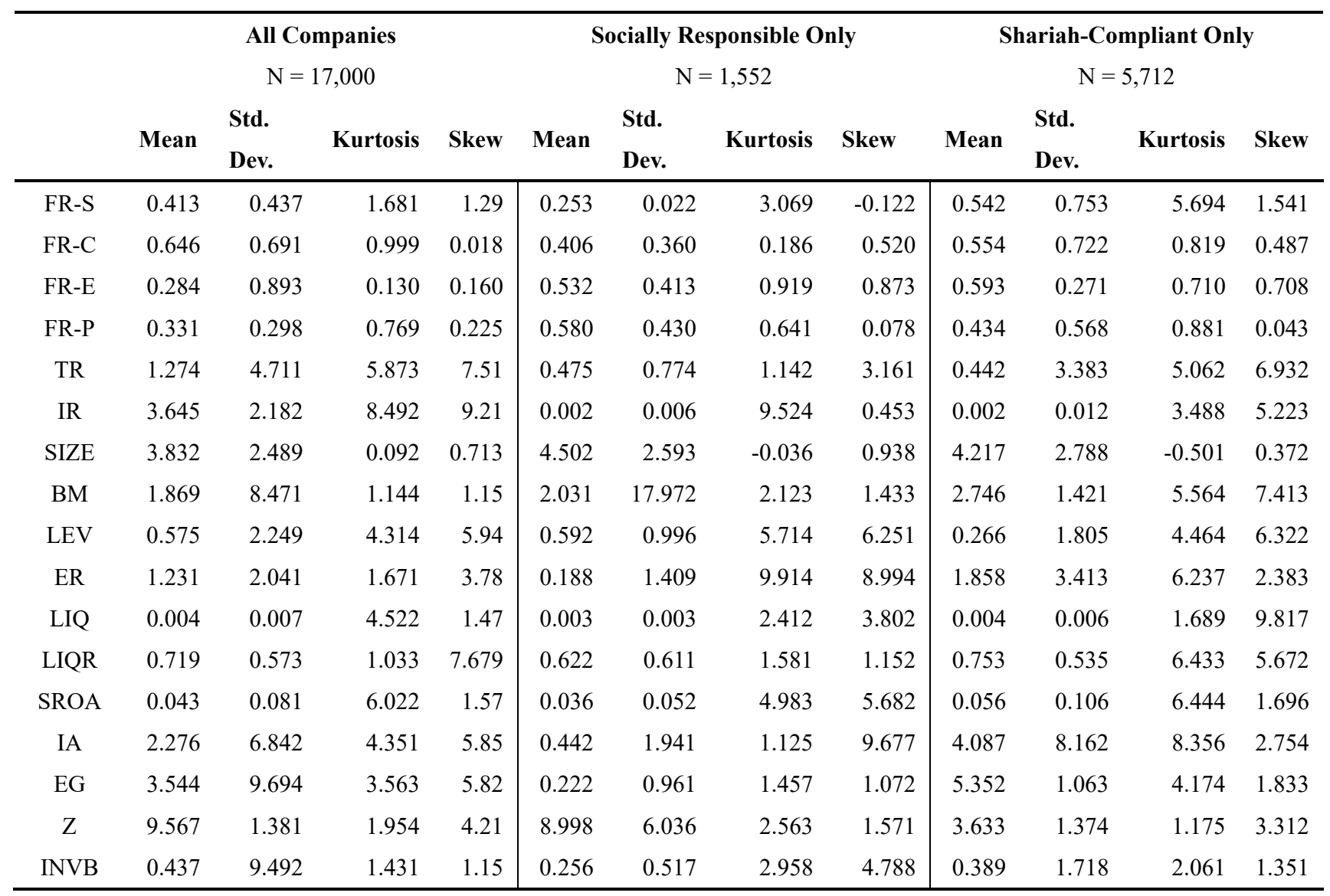

Note: FR-S = firm resilience-sales; FR-C = firm resilience-cost of goods sold; FR-E = firm-resilience - operating expenses; FR-P = firm resilience - share price; TR $=$ total risk; IR = idiosyncratic risk; $\mathrm{SIZE}=$ firm size; $\mathrm{BM}=$ book-to-market ratio; $\mathrm{LEV}=$ net leverage; $\mathrm{ER}=$ expected return; $\mathrm{LIQ}=$ stock liquidity; $\mathrm{LIQR}=$ liquidity risk; $\mathrm{SROA}=$ standard deviation of return on assets; $\mathrm{IA}=$ investment-to-asset ratio; $\mathrm{EG}=$ expected growth in earnings; $\mathrm{Z}=$ default risk; INVB = investor base.

A cursory glance at Table 2 would suggest that both SR and SC companies are not that much different from one another, especially in the dependent variables. All four firm resilience indicators for both SR and SC companies have mean values that are quite close to each other. The same can also be said of the mean values of total and idiosyncratic risk for both SR and 
SC companies. To validate these observations, we conduct a simple paired sample $t$-test to determine whether the mean difference between each of the dependent variables for SR and $\mathrm{SC}$ companies is zero. Because the SC sample is larger, 1,552 observations are randomly selected from the 5,712 to be tested. The $t$-test suggests that there is no statistically significant difference in the mean values of the dependent variables between SR and SC companies (Note 2).

\subsection{Econometric Model}

Although the $t$-test suggests that there is no statistically significant difference between SR and SC companies, it does not illustrate the effects SR or SC has on a company's level of resilience and risk. In this regard, we estimate the following model:

$$
Y_{i, t+1}=\alpha_{i}+\beta_{1} S R_{i, t}+\beta_{2} S C_{i, t}+\sum_{c=1}^{11} \beta_{3} C V_{s, i, t}+e_{i, t}
$$

where $Y_{i, t+1}$ is the four resilience indicators, total risk, and idiosyncratic risk for company $i$ at time $t+1, S R_{i t}$ is a binary variable that represents company $i$ 's listing in the Sustainability Yearbook at time $t, S C_{i t}$ is a binary variable that represents company $i$ 's Shariah-compliant status, $C V_{s, i, t}$ is a vector of independent control variables, and $e_{i t}$ is the error term. The explanatory variables are lagged one period to avoid issues of endogeneity. To reduce the interference from noise due to outliers, all variables used in this study except for the dummy variables, are winsorized at the $1 \%$ level (Oikonomou et al., 2012). Because this study employs firm-year observations, outliers and missing values may lead to spurious results, especially in the derivation of the adjusted $R^{2}$ (Baltagi, 2005). As such, missing values are accounted for through linear interpolation.

\section{Findings \& Discussion}

\subsection{Firm Resilience}

From Table 3, we can see that both SR and SC has the same effect on firm resilience. The negative sign implies that being socially responsible or Shariah-compliant results in greater firm resilience. Model (1) illustrates this simple yet statistically significant relationship. In Model (2), we can see that the relationship persists even after controlling for firm-level attributes that may have an impact on the relationship observed. In Model (3), the performance of the Dow Jones Sustainability Index (DJSI) and Dow Jones Islamic Market Index (DJIMI) is a proxy for the overall performance of the "sustainable" i.e. "socially responsible" and Shariah-compliant asset markets respectively. The interaction term SRxDJSI and SCXDJIMI tests the impact of both asset markets on SR and SC companies respectively. As we can see, the DJSI moderates the effects on a firm's resilience in operating expenses, but has little to no impact on the other indicators of resilience. The DJIMI on the other hand, moderates the effects on a firm's resilience in costs and operating expenses but has little impact on sales and share prices. We also include the variable MKT to control for the effects overall market performance may have on the relationship. The estimates suggest that market performance has little influence on the resilience of SR and SC companies.

The estimates in Table 3 provide some confirmation to the earlier $t$-test which suggested that 
there is no difference in the effects of SR and SC on firm resilience. The respective asset markets' performance on the other hand, seems to have some impact on a SR and SC company's level of resilience. The effect is particularly pronounced for SC companies. In terms of cost and operating expenses, the DJIMI has a much stronger moderating impact on SC companies' resilience than the DJSI has on SR companies. Ideally, SC companies should avoid doing business with non-halal companies, reducing their available choices of suppliers thus leaving them exposed to greater cost and expense variations. It is however, reasonable to say that the act of being socially responsible or Shariah-compliant creates greater resilience within companies due to (1) with regards to sales and share price: a greater level of trust from the public (Dhaliwal et al., 2011) and (2) with regards to costs and expenses: a greater level of managerial efficiency and discipline (Attig et al., 2013).

Table 3. Regression of Social Responsibility and Shariah-Compliance on Firm Resilience

\begin{tabular}{|c|c|c|c|c|c|c|}
\hline \multicolumn{7}{|c|}{ Dependent: Firm Resilience - Sales Revenue } \\
\hline & \multicolumn{2}{|c|}{ (1) } & \multicolumn{2}{|c|}{ (2) } & \multicolumn{2}{|c|}{ (3) } \\
\hline SR & $-0.55 * * *$ & $(-2.78)$ & $-0.32 * * *$ & $(-2.45)$ & $-0.27 * * *$ & $(-2.33)$ \\
\hline $\mathrm{SC}$ & $-0.46^{* * *}$ & $(-2.63)$ & $-0.27 * * *$ & $(-2.27)$ & $-0.28 * * *$ & $(-2.41)$ \\
\hline SRxDJSI & \multicolumn{2}{|l|}{-} & \multicolumn{2}{|l|}{-} & $-0.11 *$ & $(-1.61)$ \\
\hline SCxDJIMI & \multicolumn{2}{|l|}{-} & \multicolumn{2}{|l|}{-} & $-0.15^{*}$ & $(-1.64)$ \\
\hline MKT & \multicolumn{2}{|l|}{-} & \multicolumn{2}{|l|}{-} & $0.33 *$ & $(1.68)$ \\
\hline $\mathrm{CV}$ & \multicolumn{2}{|c|}{ NO } & \multicolumn{2}{|c|}{ YES } & \multicolumn{2}{|c|}{ YES } \\
\hline$R^{2}$ & \multicolumn{2}{|c|}{0.2143} & \multicolumn{2}{|c|}{0.2513} & \multicolumn{2}{|c|}{0.2832} \\
\hline \multicolumn{7}{|c|}{ Dependent: Firm Resilience - Cost of Goods Sold } \\
\hline & \multicolumn{2}{|c|}{ (1) } & \multicolumn{2}{|c|}{ (2) } & \multicolumn{2}{|c|}{ (3) } \\
\hline SR & $-0.75 * *$ & $(-1.89)$ & $-0.55^{* *}$ & $(-1.83)$ & $-0.43 * * *$ & $(-2.21)$ \\
\hline $\mathrm{SC}$ & $-0.56 * * *$ & $(-2.15)$ & $-0.59 * * *$ & $(-2.01)$ & $-0.51 * *$ & $(-1.91)$ \\
\hline SRxDJSI & \multicolumn{2}{|l|}{-} & \multicolumn{2}{|l|}{-} & -0.28 & $(-1.07)$ \\
\hline SCxDJIMI & \multicolumn{2}{|l|}{-} & \multicolumn{2}{|l|}{-} & $-0.75^{* *}$ & $(-1.85)$ \\
\hline MKT & \multicolumn{2}{|l|}{-} & \multicolumn{2}{|l|}{-} & 0.87 & $(0.98)$ \\
\hline $\mathrm{CV}$ & \multicolumn{2}{|c|}{ NO } & \multicolumn{2}{|c|}{ YES } & \multicolumn{2}{|c|}{ YES } \\
\hline$R^{2}$ & \multicolumn{2}{|c|}{0.1983} & \multicolumn{2}{|c|}{0.2206} & \multicolumn{2}{|c|}{0.2442} \\
\hline
\end{tabular}




\begin{tabular}{|c|c|c|c|c|c|c|}
\hline \multirow[b]{3}{*}{ SR } & \multicolumn{6}{|c|}{ Dependent: Firm Resilience - Operating Expenses } \\
\hline & \multicolumn{2}{|c|}{ (1) } & \multicolumn{2}{|c|}{ (2) } & \multicolumn{2}{|c|}{ (3) } \\
\hline & $-0.89 * * *$ & $(-2.34)$ & $-0.65^{* *}$ & $(-1.92)$ & $-0.85^{* *}$ & $(-1.93)$ \\
\hline $\mathrm{SC}$ & $-0.76^{* * *}$ & $(-3.01)$ & $-0.71 * * *$ & $(-2.22)$ & $-0.67 * *$ & $(-1.91)$ \\
\hline SRxDJSI & \multicolumn{2}{|l|}{-} & \multicolumn{2}{|l|}{-} & $-0.55 * *$ & $(-1.89)$ \\
\hline SCxDJIMI & \multicolumn{2}{|l|}{-} & \multicolumn{2}{|l|}{-} & $-0.72 * * *$ & $(-1.99)$ \\
\hline MKT & \multicolumn{2}{|l|}{-} & \multicolumn{2}{|l|}{-} & -0.11 & $(-0.78)$ \\
\hline $\mathrm{CV}$ & \multicolumn{2}{|c|}{ NO } & \multicolumn{2}{|c|}{ YES } & \multicolumn{2}{|c|}{ YES } \\
\hline$R^{2}$ & \multicolumn{2}{|c|}{0.2296} & \multicolumn{2}{|c|}{0.2199} & \multicolumn{2}{|c|}{0.2071} \\
\hline \multicolumn{7}{|c|}{ Dependent: Firm Resilience - Share Price } \\
\hline & \multicolumn{2}{|c|}{ (1) } & \multicolumn{2}{|c|}{ (2) } & \multicolumn{2}{|c|}{ (3) } \\
\hline SR & $-0.91 * * *$ & $(-3.11)$ & $-0.86 * * *$ & $(-2.88)$ & $-0.77 * * *$ & $(-3.22)$ \\
\hline $\mathrm{SC}$ & $-0.87 * * *$ & $(-2.97)$ & $-0.85^{* * *}$ & $(-2.57)$ & $-0.71 * * *$ & $(-2.76)$ \\
\hline SRxDJSI & \multicolumn{2}{|l|}{-} & \multicolumn{2}{|l|}{-} & $0.22 *$ & $(1.65)$ \\
\hline SCxDJIMI & \multicolumn{2}{|l|}{-} & \multicolumn{2}{|l|}{-} & $0.15^{*}$ & $(1.75)$ \\
\hline MKT & \multicolumn{2}{|l|}{-} & \multicolumn{2}{|l|}{-} & $0.07 *$ & (1.77) \\
\hline $\mathrm{CV}$ & \multicolumn{2}{|c|}{$\mathrm{NO}$} & \multicolumn{2}{|c|}{ YES } & \multicolumn{2}{|c|}{ YES } \\
\hline$R^{2}$ & \multicolumn{2}{|c|}{0.3104} & \multicolumn{2}{|c|}{0.3085} & \multicolumn{2}{|c|}{0.2581} \\
\hline
\end{tabular}

This table reports the estimates of coefficients of Equation 3. The dependent variables are the four firm resilience indicators. $S R$ is a binary variable that is 1 if the company is listed in the Sustainability Yearbook in the observation year; $S C$ is a binary variable that is 1 if the company is Shariah-compliant in the observation year; SRxDJSI is an interaction term between $S R$ and the excess returns on the Dow Jones Sustainability Index; SCxDJIMI is an interaction term between $S C$ and the Dow Jones Islamic Market Index; $M K T$ is the excess return on the main stock exchange of the country; and $C V$ are the firm-level control variables (see Section 3.3). All variables have been winsorized at the bottom and top $1 \%$ levels. Robust $t$-statistics are in parentheses. $* * *, * *$, and $*$ indicate statistical significance at the 1,5 and $10 \%$ levels.

\subsection{Firm Risk}

From Table 4, we can see that both SR and SC has the same effect on total risk and idiosyncratic risk. The negative sign implies that being socially responsible or Shariah-compliant lowers firm risk. The coefficient estimates in Model (1) illustrates the statistically significant negative relationship. Even with the inclusion of firm-level attributes that have been known to have an impact on firm risk, the negative effect SR and SC has on risk remains statistically significant. In Model (3) we can see that the performance of the DJSI and DJIMI has a slight moderating effect on the negative relationship between SR and $\mathrm{SC}$ on total and idiosyncratic risk. The overall performance of the market meanwhile has a statistically significant positive effect on total risk and idiosyncratic risk. The coefficient estimates in Table 4 provide further confirmation to the findings of the $t$-test i.e. there does not seem to be a difference in the effects SR and SC has on firm risk. However, we can see that the DJSI and DJIMI's performance has a greater moderating effect on total and 
idiosyncratic risk as compared to its effects on firm resilience. Due to the closer relations between companies and the smaller asset universe in the DJSI and DJIMI, it would not be unusual for the performance of the respective asset markets to have influence over the level of risk exhibited by SR and SC companies. Also, given the manner in which both total and idiosyncratic risk is derived, it is unsurprising that overall market performance has a positive impact on both measures. However, it does not detract from the fact that SR and SC reduces firm risk.

Table 4. Regression of Social Responsibility and Shariah-Compliance on Total and Idiosyncratic Risk

\begin{tabular}{|c|c|c|c|c|c|c|}
\hline \multicolumn{7}{|c|}{ Dependent: Total Risk } \\
\hline & \multicolumn{2}{|c|}{ (1) } & \multicolumn{2}{|c|}{ (2) } & \multicolumn{2}{|c|}{ (3) } \\
\hline SR & $-1.33^{* * *}$ & $(-2.01)$ & $-1.01 * *$ & $(-1.91)$ & $-1.12 * * *$ & $(-3.22)$ \\
\hline $\mathrm{SC}$ & $-1.45^{* * *}$ & $(-2.15)$ & $-1.44 * * *$ & $(-2.07)$ & $-1.51 * * *$ & $(-2.85)$ \\
\hline SRxDJSI & \multicolumn{2}{|l|}{-} & \multicolumn{2}{|l|}{-} & $-0.84 * *$ & $(-1.82)$ \\
\hline SCxDJIMI & \multicolumn{2}{|l|}{-} & \multicolumn{2}{|l|}{-} & $-0.66^{* *}$ & $(-1.90)$ \\
\hline MKT & \multicolumn{2}{|l|}{-} & \multicolumn{2}{|l|}{-} & $0.51 * *$ & $(1.78)$ \\
\hline $\mathrm{CV}$ & \multicolumn{2}{|c|}{ NO } & \multicolumn{2}{|c|}{ YES } & \multicolumn{2}{|c|}{ YES } \\
\hline$R^{2}$ & \multicolumn{2}{|c|}{0.2265} & \multicolumn{2}{|c|}{0.2315} & \multicolumn{2}{|c|}{0.2441} \\
\hline \multicolumn{7}{|c|}{ Dependent: Idiosyncratic Risk } \\
\hline & \multicolumn{2}{|l|}{ (1) } & (2) & & \multicolumn{2}{|l|}{ (3) } \\
\hline SR & $-0.033 * * *$ & $(-4.11)$ & $-0.027 * * *$ & $(-3.18)$ & $-0.031 * *$ & $(-1.91)$ \\
\hline $\mathrm{SC}$ & $-0.041^{* * *}$ & $(-2.98)$ & $-0.036^{* * *}$ & $(-2.97)$ & $-0.049 * *$ & $(-1.89)$ \\
\hline SRxDJSI & \multicolumn{2}{|l|}{-} & \multicolumn{2}{|l|}{-} & $-0.015^{*}$ & $(-1.75)$ \\
\hline SCxDJIMI & \multicolumn{2}{|l|}{-} & \multicolumn{2}{|l|}{-} & $-0.021 *$ & $(-1.72)$ \\
\hline MKT & \multicolumn{2}{|l|}{-} & \multicolumn{2}{|l|}{-} & $0.006^{*}$ & (1.61) \\
\hline $\mathrm{CV}$ & \multicolumn{2}{|c|}{ NO } & \multicolumn{2}{|c|}{ YES } & \multicolumn{2}{|c|}{ YES } \\
\hline$R^{2}$ & \multicolumn{2}{|c|}{0.2117} & \multicolumn{2}{|c|}{0.2209} & \multicolumn{2}{|c|}{0.2002} \\
\hline
\end{tabular}

This table reports the estimates of coefficients of Equation 3. The dependent variables are Total Risk and Idiosyncratic Risk. $S R$ is a binary variable that is 1 if the company is listed in the Sustainability Yearbook in the observation year; $S C$ is a binary variable that is 1 if the company is Shariah-compliant in the observation year; $S R x D J S I$ is an interaction term between $S R$ and the excess returns on the Dow Jones Sustainability Index; SCxDJIMI is an interaction term between $S C$ and the Dow Jones Islamic Market Index; $M K T$ is the excess return on the main stock exchange of the country; and $C V$ are the firm-level control variables (see Section 3.3). All variables have been winsorized at the bottom and top $1 \%$ levels. Robust $t$-statistics are in parentheses. $* * *, * *$, and $*$ indicate statistical significance at the 1,5 and $10 \%$ levels.

Understandably, some questions may arise as to the validity of the findings above given the sample period used in this study $(2007$ - 2014) during which the Global Financial Crisis (GFC) took place. To address this concern, we re-estimate Model (3) in Tables 3 and 4 using a crisis- and recovery-period sample. The crisis-period sample is from 2007 to 2010 while the recovery-period sample is from 2011 to 2014. The estimates are in Table 5 below. 
Table 5. Regression of Social Responsibility and Shariah-Compliance on Firm Resilience and Risk, Crisis and Recovery Period

\begin{tabular}{|c|c|c|c|c|c|c|}
\hline \multicolumn{7}{|c|}{ Crisis } \\
\hline & FR-S & FR-C & FR-E & FR-P & TR & IR \\
\hline \multirow[t]{2}{*}{ SR } & $-0.74 * * *$ & $-0.66 * * *$ & $-0.74 * * *$ & $-0.72 * *$ & $-1.01 * * *$ & $-0.036 * * *$ \\
\hline & $(-2.94)$ & $(-3.01)$ & $(-2.54)$ & $(-1.89)$ & $(-2.33)$ & $(-2.44)$ \\
\hline \multirow[t]{2}{*}{$\mathrm{SC}$} & $-0.55 * * *$ & $-0.77 * * *$ & $-0.70 * * *$ & $-0.68 * * *$ & $-1.51 * * *$ & $-0.085^{* *}$ \\
\hline & $(-2.22)$ & $(-1.99)$ & $(-2.48)$ & $(-2.39)$ & $(-3.11)$ & $(-2.72)$ \\
\hline \multirow[t]{2}{*}{ SRxDJSI } & $-0.78^{*}$ & -0.66 & $-0.81 * *$ & $-0.71 *$ & -0.91 & $-0.021 *$ \\
\hline & $(-1.71)$ & $(-0.91)$ & $(-1.89)$ & $(-1.77)$ & $(-0.87)$ & $(-1.81)$ \\
\hline \multirow[t]{2}{*}{ SCxDJIMI } & $-0.23^{*}$ & $-0.55^{* *}$ & $-0.71 * * *$ & $-0.44 *$ & $-0.48 * *$ & $-0.025^{*}$ \\
\hline & $(-1.72)$ & $(-1.92)$ & $(-2.08)$ & $(-1.75)$ & $(-1.89)$ & $(-1.69)$ \\
\hline \multirow[t]{2}{*}{ MKT } & -0.33 & -0.45 & -0.65 & -0.69 & $2.21^{* * *}$ & $0.207 * * *$ \\
\hline & $(-0.76)$ & $(-0.65)$ & $(-0.81)$ & $(-0.95)$ & $(3.41)$ & $(2.83)$ \\
\hline $\mathrm{CV}$ & YES & YES & YES & YES & YES & YES \\
\hline R2 & 0.2451 & 0.2401 & 0.2631 & 0.2491 & 0.1311 & 0.1446 \\
\hline \multicolumn{7}{|c|}{ Recovery } \\
\hline \multirow{3}{*}{ SR } & FR-S & FR-C & FR-E & FR-P & TR & IR \\
\hline & $-0.34 * * *$ & $-0.35 * * *$ & $-0.31 * *$ & $-0.25 * * *$ & $-1.12 * *$ & $-0.046^{* *}$ \\
\hline & $(-3.10)$ & $(-2.55)$ & $(-1.83)$ & $(-2.47)$ & $(-1.79)$ & $(-1.90)$ \\
\hline \multirow[t]{2}{*}{$\mathrm{SC}$} & $-0.37 * * *$ & $-0.47 * * *$ & $-0.40 * * *$ & $-0.36^{* *}$ & $-1.07 * *$ & $-0.073^{* * *}$ \\
\hline & $(-3.82)$ & $(-2.71)$ & $(-1.98)$ & $(-1.88)$ & $(-1.85)$ & $(-3.25)$ \\
\hline \multirow[t]{2}{*}{ SRxDJSI } & -0.82 & -0.51 & 0.49 & -0.82 & $1.49 *$ & $0.068^{*}$ \\
\hline & $(-0.43)$ & $(-0.39)$ & $(0.41)$ & $(-0.71)$ & $(1.68)$ & (1.71) \\
\hline \multirow[t]{2}{*}{ SCxDJIMI } & $-0.81 *$ & -0.69 & -0.55 & $-0.37 *$ & $-1.33^{*}$ & 0.081 \\
\hline & $(-0.61)$ & $(-0.74)$ & $(-0.33)$ & $(-0.41)$ & $(-1.65)$ & $(1.05)$ \\
\hline \multirow[t]{2}{*}{ MKT } & $1.04 *$ & 0.98 & $0.88^{* *}$ & $1.15^{*}$ & $1.45^{* *}$ & $0.741^{*}$ \\
\hline & $(1.69)$ & $(0.99)$ & $(1.88)$ & (1.71) & (1.91) & (1.88) \\
\hline $\mathrm{CV}$ & YES & YES & YES & YES & YES & YES \\
\hline $\mathrm{R} 2$ & 0.2027 & 0.2513 & 0.1984 & 0.2701 & 0.1563 & 0.1433 \\
\hline
\end{tabular}

This table reports the estimates of coefficients of Equation 3. The dependent variables are Firm Resilience - Sales Revenue (FR-S); Cost of Goods Sold (FR-C); Operating Expenses (FR-E); Share Price (FR-P); Total Risk (TR) and Idiosyncratic Risk (IR). SR is a binary variable that is 1 if the company is listed in the Sustainability Yearbook in the observation year; $S C$ is a binary variable that is 1 if the company is Shariah-compliant in the observation year; SRxDJSI is an interaction term between $S R$ and the excess returns on the Dow Jones Sustainability Index; SCXDJIMI is an interaction term between $S C$ and the Dow Jones Islamic Market Index; MKT is the excess return on the main stock exchange of the country; and $C V$ are the firm-level control variables (see Section 3.3). All variables have been winsorized at the bottom and top $1 \%$ levels. Robust $t$-statistics are in parentheses. $* * *, * *$, and * indicate statistical significance at the 1,5 and $10 \%$ levels. The Crisis period is 2007 to 2010; Recovery is 2011 to 2014. 
We can see that during the crisis period (Table 5, top panel) the performance of SR and SC companies held steady despite the turmoil in the markets. The negative relationship observed in the earlier findings is evident even with volatile market conditions. The performance of the DJSI and DJIMI however, had little to no effect on the relationship. Overall market performance likewise, did not have any influence on the resilience of SR and SC companies. The coefficient estimates during the crisis period also shows that both SR and SC companies were less risky than their counterparts, judging by the negative signs. We can also see that there is a noticeable difference in the magnitude of the effect between SR and SC on total and idiosyncratic risk.

In the recovery period (Table 5, bottom panel), we can see that the signs of the coefficient estimates have remained the same; that being socially responsible or Shariah-compliant results in greater firm resilience besides lowering firm risk. There is however, a noticeable difference in the magnitude of the relationship between the crisis and recovery period for both SR and SC. During the crisis period, the effects of SR and SC on firm resilience was greater as compared to during the recovery period, judging by the larger negative values observed. The same cannot be said about the effects of SR and SC on risk. It seems that SC companies are on the whole, less risky than others during periods of market uncertainty. When markets began to recover, the coefficient estimates suggest that SR companies were less risky. However, the estimates in both periods show that SC companies on the whole, have lower idiosyncratic risk.

\subsection{Robustness Tests}

As the CSA is conducted yearly, the constituents of the Sustainability Yearbook do not remain the same from year to year. As a company's CSR performance differs every year, there is the possibility that its performance may dip in one year and soar in the next. Even if it had maintained its performance, another company may have outperformed it. To derive additional inferences, we examine the effects listing, delisting, or maintaining one's position in the Sustainability Yearbook has on firm resilience and risk in the following year. The sample companies are categorized according to their socially responsible status at year $t$. The model is specified as follows:

$$
Y_{i, t+1}=\alpha_{i}+\beta_{1} \text { List }_{t}+\beta_{2} \text { Cont }_{t}+\beta_{3} \text { Delist }_{t}+\beta_{4} \text { DJSI }_{t}+\beta_{5} M K T_{t}+\sum_{c=1}^{11} \beta_{6} C V_{s, i, t}+e_{i, t}
$$

where List $_{t}$ is a dichotomous variable that is 1 if the company was listed in the Sustainability Yearbook at year $t$; Cont $_{t}$ is a dichotomous variable that is 1 if the company was listed in the Yearbook for at least two consecutive years; and Delist $_{t}$ is a dichotomous variable that is 1 if the company was dropped from the Yearbook. Definitions of the remaining variables are the same as Equation 3. 
Table 6. Regression of Change in Socially Responsible Status on Firm Resilience and Risk

\begin{tabular}{lrrrrrr}
\hline & \multicolumn{1}{l}{ FR-S } & \multicolumn{1}{c}{ FR-C } & \multicolumn{1}{c}{ FR-E } & \multicolumn{1}{c}{ FR-P } & \multicolumn{1}{c}{ TR } & \multicolumn{1}{c}{ IR } \\
\hline List & $-0.81^{* * *}$ & $-0.71^{* * *}$ & $-0.77^{* * *}$ & $-0.85^{* * *}$ & $-1.71^{* * *}$ & $-0.075^{* * *}$ \\
& $(-2.44)$ & $(-2.71)$ & $(-2.85)$ & $(-2.21)$ & $(-2.48)$ & $(-2.33)$ \\
\multirow{2}{*}{ Maintain } & $-0.65^{* * *}$ & $-0.53^{* * *}$ & $-0.62^{* * *}$ & $-0.79^{* * *}$ & $-1.52^{* *}$ & $-0.055^{* *}$ \\
& $(-3.01)$ & $(-2.61)$ & $(-2.35)$ & $(-2.11)$ & $(-1.90)$ & $(-1.85)$ \\
Delist & $0.11^{* *}$ & $-0.21^{*}$ & $0.25 * * *$ & $0.31^{* *}$ & $0.67^{* *}$ & $0.042^{*}$ \\
& $(1.85)$ & $(-1.65)$ & $(2.01)$ & $(1.89)$ & $(1.92)$ & $(1.70)$ \\
DJSI & -0.32 & -0.65 & -0.36 & $0.41^{*}$ & $-1.22^{*}$ & $0.021^{*}$ \\
& $(-0.76)$ & $(-0.61)$ & $(-0.53)$ & $(1.71)$ & $(-1.79)$ & $(1.68)$ \\
MKT & 0.65 & 0.43 & 0.25 & $0.78^{*}$ & $0.99 *$ & $0.051^{*}$ \\
& $(0.81)$ & $(0.76)$ & $(0.61)$ & $(1.65)$ & $(1.77)$ & $(1.81)$ \\
CV & YES & YES & YES & YES & YES & YES \\
R2 & 0.2581 & 0.2375 & 0.1961 & 0.2103 & 0.1638 & 0.1748 \\
\hline
\end{tabular}

This table reports the estimates of coefficients of Equation 4. The dependent variables are Firm Resilience - Sales Revenue (FR-S); Cost of Goods Sold (FR-C); Operating Expenses (FR-E); Share Price (FR-P); Total Risk (TR) and Idiosyncratic Risk (IR). DJSI is the excess returns on the Dow Jones Sustainability Index; $M K T$ is the excess return on the main stock exchange of the country; and $C V$ are the firm-level control variables (see Section 3.3). All variables have been winsorized at the bottom and top $1 \%$ levels. Robust $t$-statistics are in parentheses. $* * *, * *$, and $*$ indicate statistical significance at the 1,5 and $10 \%$ levels.

In Table 6, we can see a distinct difference in the effects a company's status in the Sustainability Yearbook has on firm resilience and risk. Companies that were listed in the Yearbook either for the first time or were re-listed following a delisting experienced greater firm resilience and lower firm risk in the year after listing. The same effect can also be observed for companies that maintained their positions in the Yearbook. We can however see that newly listed or relisted companies recorded greater firm resilience and lower firm risk as compared to companies that were continuously listed. In contrast, companies that were delisted from the Yearbook saw lower firm resilience and greater firm risk in the following year.

Re-estimating Equation 4 using the SC sample yields the coefficient estimates in Table 7. Companies that were newly listed or re-listed as Shariah-compliant exhibited greater firm resilience and lower risk in the following year. Companies that were continuously Shariah-compliant for at least two years (i.e. "Maintain") exhibited similar traits but as was seen in Table 6, those that were newly listed or re-listed displayed a much stronger effect that those that maintained their status. On the other hand, those that were delisted saw lower firm resilience and greater risk in the following year. 
Table 7. Regression of Change in Shariah-Compliant Status on Firm Resilience and Risk

\begin{tabular}{lllllll}
\hline & \multicolumn{1}{c}{ FR-S } & \multicolumn{1}{c}{ FR-C } & \multicolumn{1}{c}{ FR-E } & FR-P & TR & IR \\
\hline List & $-1.04^{* * *}$ & $-0.98^{* * *}$ & $-0.85^{* * *}$ & $-0.45^{* * *}$ & $-1.21^{* * *}$ & $-0.078^{* * *}$ \\
& $(-2.94)$ & $(-3.22)$ & $(-2.58)$ & $(-2.32)$ & $(-3.63)$ & $(-2.88)$ \\
Maintain & $-0.87^{* * *}$ & $-0.76^{* *}$ & $-0.68^{* * *}$ & $-0.51^{* *}$ & $-1.05^{* *}$ & $-0.077^{* * *}$ \\
& $(-3.45)$ & $(-1.93)$ & $(-3.05)$ & $(-1.89)$ & $(-1.81)$ & $(-2.71)$ \\
Delist & $1.13^{* *}$ & $0.88^{* *}$ & $0.76^{* *}$ & $0.58^{* * *}$ & $1.31^{* * *}$ & $0.078^{*}$ \\
& $(1.89)$ & $(1.81)$ & $(1.76)$ & $(3.11)$ & $(2.71)$ & $(1.58)$ \\
DJIMI & $0.83^{*}$ & 0.78 & 0.90 & $0.65^{*}$ & $0.85^{*}$ & $0.072^{*}$ \\
& $(1.65)$ & $(0.99)$ & $(1.13)$ & $(1.66)$ & $(1.70)$ & $(1.67)$ \\
MKT & 0.91 & 0.78 & 0.44 & $0.65^{* *}$ & $1.33^{*}$ & 0.044 \\
& $(0.11)$ & $(1.16)$ & $(1.02)$ & $(1.81)$ & $(1.71)$ & $(0.88)$ \\
CV & YES & YES & YES & YES & YES & YES \\
\hline
\end{tabular}

This table reports the estimates of coefficients of Equation 4. The dependent variables are Firm Resilience - Sales Revenue (FR-S); Cost of Goods Sold (FR-C); Operating Expenses (FR-E); Share Price (FR-P); Total Risk (TR) and Idiosyncratic Risk (IR). DJIMI is the excess returns on the Dow Jones Islamic Market Index; $M K T$ is the excess return on the main stock exchange of the country; and $C V$ are the firm-level control variables (see Section 3.3). All variables have been winsorized at the bottom and top $1 \%$ levels. Robust $t$-statistics are in parentheses. $* * *, * *$, and * indicate statistical significance at the 1,5 and $10 \%$ levels.

From the observations in Tables 6 and 7, it would seem that the company's status as socially responsible or Shariah-compliant has an observable impact on its resilience and levels of risk. But far from being a simple direct relationship between status and resilience/risk, it would have been the result of the company's (in)actions towards acquiring said status that would also have had an impact on its resilience and risk. For example, companies that seek to be Shariah-compliant are restricted to only a few industries that do not incite controversy. As they attract less negative attention, their reputation and credibility in eyes of their various stakeholders are better protected, providing greater stability whilst possibly attracting goodwill in the process The restrictions on the amount of risky instruments it may hold such as debt or interest-earning assets meanwhile, lessens the impact of negative market-level shocks on the company thereby lowering firm risk. Socially responsible companies go through a similar process. The social responsibility initiatives they undertake culminate in the awarding of the socially responsible status. Prior studies on CSR agree that although the impact each initiative (economic, social, environmental) has on the company is widely divergent (see for example Bird et al., 2011; Muhammad et al., 2013), CSR results in greater stability and lower risks.

What the findings above imply is the argument that there is an 'Islamization' of cultures especially in the West is unfounded, given the profound similarities between the principles and practices of Islamic and Western ethical philosophy. The attack on halal industries have likewise, been unfair because as the findings above show, there is no observable difference in 
the impact Shariah-compliance or social responsibility has on companies. As the literature has suggested, many parallels can be drawn between Islamic principles and the Western 'ideals' of ethics and morality. The new wave of socio-politics that have driven a divide between Muslims and non-Muslims are merely fought on ideological grounds. As far as businesses go, this study shows that the alleged 'concerns' raised by political opportunists and other members of the public playing devil's advocate are merely tools to gain political leverage and have no basis in fact.

Rather than simply being a study on ideological differences, the findings of this study also paves the way for better cooperation and integration in the practice of social responsibility and Shariah-compliance. Currently, the greatest obstacle faced by regulators with regards to Shariah-compliance assessment is the lack of consensus on the criteria used (Derigs and Marzban, 2008). Institutions such as Robeco SAM meanwhile have successfully created and implemented an objective and consistent method of assessing a company's corporate social responsibility performance. By providing evidence that the effects of Shariah-compliance or social responsibility on companies are similar, regulators can begin to draft more objective and consistent methods of assessing Shariah-compliance that can be practiced universally. Although Shariah-compliance is a binary condition, this study also provides an opportunity for future research to develop a performance scorecard for Shariah-compliance much like what RobecoSAM has done with its annual CSA. An adaptation of the CSA, the scorecard would highlight aspects of the company that has been compliant as well as areas that need improvement which would then be published in the form of an annual report. Dissemination of such information fosters a greater understanding of Islamic teachings and lends credibility to the arguments made proponents of Shariah-compliance, leading to the cessation of unfair attacks on halal industries.

\section{Conclusion}

Despite what is reported, Islamic ethics shares many parallels with those that many Western civilizations have come to accept. Although this is not the first time these parallels have been drawn, this study is the first to test these claims empirically. A common yardstick for business ethics and morality in recent years has been a company's commitment to social and environmental responsibility. While there is as yet no Islamic equivalent, Shariah-compliance is a reasonable approximation since its qualifying criteria are based on the principles set within the Quran and prescribed by the Sunnah. By comparing the effects practice of these two seemingly different ethical schools of thought, this study provides the empirical evidence to show that where business ethics, Islamic or otherwise is concerned, they are both similar in substance as well as form. Future studies would do well to focus on developing a unified framework for the assessment of social responsibility and Shariah-compliance to foster greater unity within ethical business practices.

\section{Notes}

Note 1. The countries observed in this study are Argentina, Brazil, China, Hungary, Indonesia, Malaysia, Mexico, the Philippines, Poland, Russia, South Africa, Thailand, Turkey, and Vietnam. 
Note 2. For brevity, we did not present the results of the $t$-test here. They are however, available upon request.

\section{References}

Abdelsalam, O., Fethi, M. D., Matallin, J. C., \& Tortosa-Ausina, E. (2014). On the comparative performance of socially responsible and Islamic mutual funds. Journal of Economic Behavior \& Organization, 103, S108-S128, https://doi.org/10.1016/j.jebo.2013.06.011

Alam, N., \& Rajjaque, M. S. (2010) Shariah-compliant equities: Empirical evaluation of performance in the European market during credit crunch, Journal of Financial Services Marketing, 15, 228-240. https://doi.org/10.1057/fsm.2010.19

Albaity, M., \& Ahmad, R. (2008). Performance of Syariah and Composite Indices: Evidence from Bursa Malaysia. Asian Academy of Management Journal of Accounting and Finance, 4, $23-43$.

Altman, E. (1993). Corporate Financial Distress and Bankruptcy. New York: John Wiley.

Attig, N., El Ghoul, S., Guedhami, O., \& Suh, J. (2013). Corporate Social Responsibility and Credit Ratings. Journal of Business Ethics, 117(4), 679-694, https://doi.org/10.1007/s10551-013-1714-2

Balabanis, G., Phillips H. C. and Lyall, J. (1998). Corporate social responsibility and economic performance in the top British companies: are they linked? European Business Review, 98, 25-44. https://doi.org/10.1108/09555349810195529

Baltagi, B. H. (2005). Econometric analysis of panel data. New York: Wiley.

Bates, T. W., Kahle, K. M., \& Stulz, R. (2009). Why do US firms hold so much more cash than they used to? Journal of Finance, 64, 1985-2021. https://doi.org/10.1111/j.1540-6261.2009.01492.x

BBC. (2015). Shell agrees $\$ 84 \mathrm{~m}$ deal over Niger Delta oil spill. Retrieved 15 December 2015 from http://www.bbc.com/news/world-30699787

Beekun, R. I., \& J. A. Badawi. (2005). Balancing Ethical Responsibility Among Multiple Organizational Stakeholders: The Islamic Perspective. Journal of Business Ethics, 60, 131-145, https://doi.org/10.1007/s10551-004-8204-5

Bird, R., Momente, F., \& Reggiani, F. (2011). The market acceptance of corporate social responsibility: a comparison across six countries / regions. Australian Journal of Management, 37(2), 153-168. https://doi.org/10.1177\%2F0312896211416136

Botosan, C. A., \& Plumlee, M. A. (2005). Assessing alternative proxies for the expected risk premium. The Accounting Review, 80, 21-53. https://www.jstor.org/stable/4093160

Bouslah, K., Kryzanowski, L., \& M'Zali, B. (2013). The impact of the dimensions of social performance on firm risk. Journal of Banking \& Finance, 37, 1258-1273. https://doi.org/10.1016/j.jbankfin.2012.12.004 
Brennan, M. J., Chordia, T., \& Subrahmanyam, A. (1998). Alternative factor specifications, security characteristics, and the cross-section of expected stock returns. Journal of Financial Economics, 49, 345-373. https://doi.org/10.1016/S0304-405X(98)00028-2

Carhart, M. M. (1997). On persistence in mutual fund performance. Journal of Finance, 52, 57-82. https://www.jstor.org/stable/2329556

Chapra, M. U. (2000). The Future of Economics: An Islamic Perspective (The Islamic Foundation, Leicester), pp. 147-148.

Chordia, T., Subrahmanyam, A., \& R., A. (2001). Trading activity and expected stock returns. Journal of Financial Economics, 59, 3-32. https://doi.org/10.1016/S0304-405X(00)00080-5

Dali, N. R. S., Mudasir, M. M., \& Abdul Hamid, S. (2008). Performance of Shariah compliance companies in the plantation industry, International Journal of Islamic and Middle Eastern Finance and Management, 1, 166-178. https://doi.org/10.1108/17538390810881008

Davidson, W. N., \& Worrell D. L. (1988). The impact of announcements of corporate illegalities on shareholder returns, Academy of Management Journal, 31, 195-200. https://www.jstor.org/stable/256506

Davidson, W. N., Worrell, D. L., \& Lee, C. I. (1994). Stock market reactions to announced corporate illegalities. Journal of Business Ethics, 13, 979-987, https://doi.org/10.1007/BF00881667

Derigs, U., \& Marzban, S. (2008). Review and Analysis of Current Shariah-compliant Equity Screening Practices. International Journal of Islamic and Middle Eastern Finance and Management, 1(4), 285-303. https://doi.org/10.1108/17538390810919600

Derigs, U., \& Marzban, S. (2009). New strategies and new paradigm for Shariah-compliant portfolio optimization. Journal of Banking and Finance, 33, 1166-1176. https://doi.org/10.1016/j.jbankfin.2008.12.011

Dhaliwal, D., Li, O., Zhang, A., \& Yang, Y. (2011). Voluntary nonfinancial disclosure and the cost of equity capital: The initiations of corporate social responsibility reporting. Accounting Review, 86, 59-100. https://www.jstor.org/stable/29780225

Drees, W. B., \& van Koningsveld, P. S. (eds) (2008). The Study of Religion and the Training of Muslim Clergy in Europe: Academic and Religious Freedom in the $21^{\text {st }}$ Century. Leiden University Press, Netherlands.

Durand, R. B., Koh S. K., \& Limkriangkrai, M. (2013). Saints versus sinners. Does morality matter? Journal of International Financial Markets, Institutions \& Money, 24, 166-183. https://doi.org/10.1016/j.intfin.2012.12.002

El Gamal, M. A. (2000). A Basic Guide to Contemporary Islamic Banking and Finance. Houston: Rice University.

Elfakhani, S., Hassan, M. K. and Sidani, Y. (2005). Comparative performance of Islamic versus secular mutual funds. American University of Beirut Working Paper. 
Fama, E. F., \& French, K. R. (1992). The cross-section of expected stock returns. Journal of Finance, 47, 427-465. https://doi.org/10.1111/j.1540-6261.1992.tb04398.x

Fama, E. F., \& French, K. R. (1993). Common risk factors in the returns on stocks and bonds. Journal of Financial Economics, 33, 3-56. https://doi.org/10.1016/0304-405X(93)90023-5

Feldman, S. J., Soyka, P., \& Ameer, P. G. (1997). Does improving a firm's environmental management system and environmental performance result in a higher stock price? Journal of Investing, 6, 87-97. https://doi.org/10.3905/joi.1997.87

Gebhardt, W., Lee, C., \& Swaminathan, B. (2001). Toward an implied cost of capital. Journal of Accounting Research, 39, 135-176. https://doi.org/10.1111/1475-679X.00007

Hakim, S., \& Rashidian, M. (2004). How costly is investors' compliance with Sharia? ERF Eleventh Annual Conference. Beirut.

Haykal, M. H. (1976). The Life of Muhammad. Delhi: Crescent Publishing.

Hoepner, A. G. F., Rammal, H. G., \& Rezec, M. (2011). Islamic mutual funds' financial performance and international investment style: evidence from 20 countries, The European Journal of Finance, 17, 829-850. https://doi.org/10.1080/1351847X.2010.538521

Jo, H., \& Na, H. (2012). Does CSR reduce firm risk? Evidence from controversial industry sectors. Journal of Business Ethics.

Khan, F. (2010). How 'Islamic' is Islamic Banking? Journal of Economic Behavior \& Organization, 76, 805-820. https://doi.org/10.1016/j.jebo.2010.09.015

Khatkatay, M. H., \& Nisar, S. (2006). Shariah Compliant Equity Investments: An Assessment of Current Screening Norms. Seventh Harvard University Forum on Islamic Finance, (pp. 1-37). Massachusetts.

Khatkatay, M. H., \& Nisar, S. (2007). Shariah Compliant Equity Investments: An Assessment of Current Screening Norms. Islamic Economic Studies, 15(1), 47-76.

Kotha, S., Rajgopal, S., \& Rindova, V. (2001). Reputation building and performance: An empirical analysis of the top-50 pure internet firms, European Management Journal, 19(6), 571-586. https://doi.org/10.1016/S0263-2373(01)00083-4

Lev, B., Petrovits, C., \& Radhakrishnan, S. (2010). Is doing good good for you? How corporate charitable contributions enhance revenue growth, Strategic Management Journal, 31(2), 182-200. https://doi.org/10.1002/smj.810

McGuire, J. B., Sundgren, A., \& Schneeweis, T. (1988). Corporate social responsibility and firm financial performance. Academy of Management Journal, 31, 854-872, https://www.jstor.org/stable/256342

McWilliams, A., \& Siegel, D. (2000). Corporate social responsibility and financial performance: Correlation or misspecification? Strategic Management Journal, 21, 603-609, https://doi.org/10.1002/(SICI)1097-0266(200005)21:5\%3C603::AID-SMJ101\%3E3.0.CO;23 
Merton, R.C. (1987). A simple model of capital market equilibrium with incomplete information. Journal of Finance 42, 483-510, https://doi.org/10.1111/j.1540-6261.1987.tb04565.x

Muhammad, N., Scrimgeour, F., Reddy, K., \& Abidin, S. (2015). The impact of corporate environmental performance on market risk: The Australian industry case. Journal of Business Ethics, 132, 347-362. https://doi.org/10.1007/s10551-014-2324-3

Murray, A., Sinclair, D., Power, D., \& Gray, R. (2006). Do financial markets care about social and environmental disclosure? Further evidence and exploration from the UK. Accounting, Auditing $\quad \& \quad$ Accountability 228-255, https://doi.org/10.1108/09513570610656105

Nomani, F. (2006). The dilemma of riba-free banking in Islamic public policy. In: Behdad, S., Nomani, F. (Eds.), Islam and the Everyday World: Public Policy Dilemmas. Routledge, London, pp. 193-223

Oikonomou, I., Brooks, C., \& Pavelin, S. (2012). The impact of corporate social performance on financial risk and utility: A longitudinal analysis. Financial Management, 41(2), 483-515, https://doi.org/10.1111/j.1755-053X.2012.01190.x

Pricewaterhouse Coopers. (2010). Open to comparison: Islamic finance and IFRS. United Kingdom: PricewaterhouseCoopers.

Rose, A. (2004). Defining and measuring economic resilience to disasters, Disaster Prevention and Management: An International Journal, 13(4), 307-314. https://doi.org/10.1108/09653560410556528

Shadid, W., \& van Koningsveld, P. S. (2002). The negative image of Islam and Muslims in the West, in Shadid, W., and P. S. van Koningsveld (eds) (2002): Religious freedom and the neutrality of the state: The position of Islam in the European Union. Leuven, Peeters, pp. 174-196.

Shadid, W., \& van Koningsveld, P. S. (2005). Muslim dress in Europe: Debates on the headscarf, Journal of Islamic Studies, 16(1), 35-61. https://doi.org/10.1093/jis/16.1.35

Sharfman, M. P., \& Fernando, C. S. (2008). Environmental risk management and the cost of capital. Strategic Management Journal, 29, 569-592. https://doi.org/10.1002/smj.678

Stanwick, P. A., \& Stanwick S. D. (1998). The relationship between corporate social performance and organizational size, financial performance and environmental performance: An empirical examination. Journal of Business Ethics, 17, 195-204, https://doi.org/10.1023/A:1005784421547

Surroca, J., Tribo, J. A., \& Waddock, S. (2010). Corporate responsibility and financial performance: The role of intangible resources. Strategic Management Journal, 31, 463-490, https://doi.org/10.1002/smj.820

United Nations Development Programme (UNDP). (2002). Arab Human Development 
Report 2002 (United Nations Publications, New York).

Waddock, S. A., \& Graves, S. B. (1997). The corporate social performance-financial performance link. Strategic Management Journal, 18, 303-319', https://doi.org/10.1002/(SICI)1097-0266(199704)18:4\%3C303::AID-SMJ869\%3E3.0.CO;2G

Williams, G., \& Zinkins, J. (2010). Islam and CSR: A study of the compatibility between the tenets of Islam and the UN Global Compact, Journal of Business Ethics, 91, 519-533, https://doi.org/10.1007/s10551-009-0097-X

Zaman, M.R. (2002). Interest free Islamic banking: ideals and reality. International Journal of Finance, 14, 2428-2442.

\section{Copyright Disclaimer}

Copyright for this article is retained by the author(s), with first publication rights granted to the journal.

This is an open-access article distributed under the terms and conditions of the Creative Commons Attribution license (http://creativecommons.org/licenses/by/3.0/). 